\title{
Kemandirian Wanita Tani dalam Usaha Industri Pangan di Solo Raya Jawa Tengah
}

\section{Self-Reliance of Women Farmers on Food Industries at Solo Raya Region Central Java}

\author{
Suminah $^{1}$, Sunarru Samsi Hariadi ${ }^{2}$, Mei Tri Sundari ${ }^{3}$, Arip Wijianto ${ }^{4}$ \\ 1,3,4Fakultas Pertanian, Universitas Negeri Sebelas Maret Surakarta, Surakarta \\ ${ }^{2}$ Fakultas Pertanian, Universitas Gadjah Mada, Yogyakarta
}

\begin{abstract}
Independence of women farmers in food business needs social support as well as motivation from themselves. The purpose of this study was (1) to describe social support, motivation, and self-reliance, (2) to analyze the effect of variable social support as well as motivation towards self-reliance of women farmers in the food business. Studies were carried out in the region of Solo Raya, Central Java, Indonesia. This study used a quantitative method, with survey techniques. Samples were taken as many as 210 respondents with a multi-stage random sampling technique. Data were analyzed descriptively, and the influence were tested with structural equation modeling (SEM). The results confirmed that 52.4\% of social support was in the medium category, motivated $(100 \%)$ and self-reliance of (59.5\%) were in the high category. Social support plus motivation simultaneously have a determinant value $\left(R^{2}\right)=0.05$. This means that only $5 \%$ contribution of social support and motivation were given towards independence, and this is because the recent form of social support provided is inappropriate, resulting in less impact on improving motivation and independence of women farmers in food industries efforts. Direct social support and motivation significantly affect independence. Social support indirectly have a greater effect on the independence of women farmers if mediated by motivation.
\end{abstract}

Keywords : Social support, motivation, self-reliance

\begin{abstract}
Abstrak
Kemandirian wanita tani dalam usaha industri pangan membutuhkan social support dari pihak lain dan motivasi dari wanita tani. Penelitian ini bertujuan untuk (1) mendeskripsikan sosial support, motivasi, dan kemandirian, (2) menganalisis pengaruh variabel dukungan sosial maupun motivasi terhadap kemandirian wanita tani dalam usaha industri pengolahan pangan. Studi dilakukan di wilayah Solo Raya, Jawa Tengah. Pada penelitian ini digunakan metode kuantitatif, dengan teknik survey. Sampel diambil sebanyak 210 responden dengan teknik sampling acak bertahap. Data dianalisis secara deskriptif, dan diuji pengaruhnya dengan model persamaan struktural (SEM). Berdasarkan hasil analisis dapat dijelaskan bahwa sebanyak 52,4\% dukungan dari berbagai pihak seperti keluarga, teman, pemimpin, petugas pemberdayaan, dan instansi lain termasuk kategori sedang. Motivasi wanita tani $100 \%$ berada pada kategori tinggi, dan kemandirian wanita tani untuk melakukan usaha industri pangan $59,5 \%$ termasuk kategori tinggi. Sosial support dan motivasi secara simultan memiliki nilai determinant $\left(R^{2}\right)=0,05$. Kecilnya kontribusi sosial support dan motivasi terhadap kemandirian wanita tani dalam menjalankan usaha industri pangan, disebabkan karena bentuk dukungan sosial yang diberikan selama ini kurang tepat, sehingga kurang berdampak pada peningkatan motivasi dan kemandirian wanita tani dalam usaha indutri pangan. Dukungan sosial dan motivasi secara langsung berpengaruh significan terhadap kemandirian. Dukungan sosial secara tidak langsung memiliki pengaruh lebih besar pada kemandirian wanita tani jika dimediasi oleh motivasi.
\end{abstract}

Kata kunci : Dukungan sosial, motivasi, kemandirian

\section{Pendahuluan}

Pemberdayaan terhadap wanita tani untuk melakukan usaha industri makanan di Solo Raya, Jawa Tengah secara berkelanjutan sudah lama dilakukan, tetapi mengindikasikan masih banyak wanita tani pelaku usaha yang belum mandiri dalam melakukan usaha industri pangan, kurang ada peningkatan dalam usahanya, bahkan sebagian besar mereka sudah tidak melakukan usaha lagi, peralatan yang sudah diberikan banyak yang mangkrak (tidak difungsikan), demikian juga dengan modal

\footnotetext{
${ }^{1}$ Korespondensi penulis

E-mail:sum_anan@yahoo.com
}

yang telah diberikan sudah tidak digunakan lagi untuk usaha. Di lain pihak, ada juga yang berhasil, padahal fasilitasi program yang dilakukan serupa. Berbagai bentuk fasilitasi yang selama ini dilakukan adalah meningkatkan pengetahuan dan ketrampilan wanita tani berdasarkan potensi yang dimiliki, diberi informasi tentang bagaimana merencanakan suatu usaha, bagaimana menjalin kerjasama, pengembangan usaha, dan diberikan sarana prasarana seperti peralatan, dan permodalan sehingga diharapkan nantinya sasaran termotivasi untuk meningkatkan usaha industri pangan. 
Hasil survey awal memperlihatkan ada $13,07 \%$ wanita tani yang mandiri dalam melakukan usaha industri pangan, selebihnya belum mandiri. Untuk meningkatkan kemandirian dalam usaha industri pangan bagi wanita tani, selain berbagai bentuk dukungan sosial dari berbagai pihak yang telah diberikan baik melalui proses pembelajaran maupun dalam bentuk charity, ada dugaan bahwa juga terjadi karena adanya kekuatan psikologis yang positif yang memberi penguatan seperti motivasi. Psikologi positif (positive psychology) adalah studi tentang kondisi dan proses yang berpengaruh pada pengembangan dan optimalisasi fungsi dari individu, kelompok, atau institusi (Betz, 2007). Berdasarkan penjelasan yang telah dipaparkan tersebut di atas, maka timbulah pertanyaan penelitian tentang seberapa besar kekuatan variabel social support dan motivasi secara simultan berpengaruh terhadap kemandirian wanita tani dalam melakukan usaha industri pangan.

Kemandirian yang dimaksud dalam studi ini, mengacu pada beberapa tinjauan pustaka dan landasan teori, yang menjelaskan bahwa kemandirian adalah merupakan perilaku yang aktivitasnya berdasarkan atas kemampuan sendiri dalam mencapai kepuasan dari perilaku eksploratif, mampu memanipulasi lingkungannya, yang perilakunya ditandai oleh: mampu menyelesaikan masalah yang dihadapi, berani mengambil resiko atas tindakan yang dilakukan, punya insiatif, inovatif, kreatif dalam melaksanakan kegiatan, berdaya saing, mampu mengambil keputusan atas dirinya sendiri dan mengerjakan sesuatu tanpa tergantung pada orang lain, dan memperoleh kepuasan dari usahanya, (Johnson dan Medinus, 1974; Spancer, 1970; Banardib, 2002; Farid, 2008).

Kemandirian merupakan salah satu indikator keberhasilan dari adanya program pemberdayaan dapat dipengaruhi oleh berbagai faktor. Teori Kurt Lewin dalam studi ini dijadikan sebagai landasan teori, yang merumuskan bahwa perilaku (behavior) individu dipengaruhi oleh keadaan diri pribadi (personality) dan lingkungannya (environment), dengan membuat persamaan dasar perilaku manusia adalah $\mathrm{B}=\mathrm{f}(\mathrm{P}, \mathrm{E})$, artinya bahwa perilaku $(\mathrm{B})$ adalah fungsi dari faktor-faktor atau karakteristik yang bersifat individual yang cenderung ke psikologis (P) dengan situasi dan kondisi lingkungan di mana individu berada (E) (Schultz and Schultz, 1992). Sesuai dengan teori tersebut bahwa kemandirian wanita tani dalam melakukan usaha industri pangan ditunjukkan oleh perilakunya sebagai salah satu indikator keberhasilan pemberdayaan perempuan yang dipengaruhi oleh faktor personality dan faktor lingkungan (environment).

Kemandirian (self-reliance) adalah suatu suasana atau kondisi tertentu yang membuat seorang individu atau sekelompok manusia yang telah mencapai kondisi tidak lagi tergantung pada bantuan atau kedermawanan pihak ketiga untuk mengamankan kepentingan individu atau kelompok, (Verhagen, 1996). Dengan kata lain, kemandirian adalah kemampuan memilih berbagai alternatif yang tersedia agar dapat digunakan untuk melangsungkan kehidupan yang serasi dan berkelanjutan. Individu yang memiliki autonomy (mandiri), perilakunya merupakan kekuatan atau dorongan dari dalam dan tindakan karena pengaruh orang lain, mempunyai kontrol diri, mampu mengembangkan sikap kritis, dan mampu membuat keputusan secara bebas (Brawer, 1973). Menurut Watson dan Lindgren (1999) tingkah laku mandiri meliputi: pengambilan inisiatif, mengatasi kendala, melakukan sesuatu dengan tepat, gigih dalam usahanya, dan melakukan sesuatu sendiri tanpa bantuan orang lain.

Kemandirian merupakan salah satu komponen sikap individu dalam merespons proses pemberdayaan, sehingga mampu menggunakan sumberdaya sendiri berdasarkan pengetahuan yang diperoleh, kerja sendiri dan dalam lingkungan yang diciptakan sendiri berdasarkan ketrampilan yang diperoleh. Kemandirian bukan berarti mampu hidup sendiri, tetapi mandiri dalam pengambilan keputusan, yaitu mempunyai kemampuan untuk memilih dan berani untuk menolak segala bentuk kerjasama yang tidak menguntungkan (Ife dan Tesoriero, 2008).

Spancer dan Kass (1970) mengatakan bahwa individu yang mandiri memiliki ciri-ciri: mampu mengambil inisiatif, mampu mengatasi masalah, penuh ketekunan, memperoleh kepuasan dari usahanya, dan mengerjakan sesuatu tanpa bantuan orang lain. Dukungan sosial dapat dijadikan dorongan individu untuk terlibat aktif terhadap bidang yang diminatinya, terutama wirausaha yang membutuhkan keuletan, keberanian, dan kreativitas, mandiri dengan kemampuan yang ada pada diri sendiri. Kemandirian bukan merupakan bawaan sejak lahir, tetapi muncul dan berubah seiring dengan pengalaman dan perkembangannya (Crow dan Crow, 1993).

Dalam melakukan usaha industri pangan wanita tani sebagai individu yang memiliki kemandirian harus mampu mengambil keputusan dalam mengorganisir sumberdaya yang ada. Selain 
itu individu mampu mencari kreativitas yang inovatif dalam mengatasi kendala. Sebagaimana dikatakan oleh Sumodiningrat (1996) salah satu indikator keberhasilan pelaksanaan program pemberdayaan adalah berkurangnya jumlah penduduk miskin, berkembangnya usaha peningkatan pendapatan yang dilakukan penduduk miskin dengan memanfatkan sumberdaya yang tersedia, dan meningkatnya kemandirian yang ditandai dengan semakin berkembangnya usaha industri pangan anggota dan kelompok, makin kuatnya permodalan kelompok, makin rapinya sistem administrasi kelompok serta makin luasnya interaksi kelompok lain di dalam masyarakat. Mengingat pentingnya kemandirian bagi kehidupan manusia maka kemandirian wanita tani perlu memperoleh perhatian, agar kemandirian tersebut dapat berkembang secara optimal.

Social support menurut House and Smet (1994) adalah: (1) dukungan emosional, mencakup ungkapan empati, kepedulian dan perhatian kepada orang yang memerlukan sehingga dukungan tersebut memberikan rasa nyaman dan rasa mengasihi, rasa saling memiliki dan rasa untuk dicintai; (2) dukungan penghargaan, meliputi ungkapan hormat, motivasi untuk maju, menyetujui idenya atau persamaan individu dan perbandingan positif individu tersebut dengan orang lain; (3) dukungan instrumental, meliputi bantuan secara langsung sesuai dengan yang dibutuhkan oleh seseorang, misalnya menyediakan sarana atau alat bantu; (4) dukungan informatif, mencakup memberi nasihat, saran, petunjuk, dan umpan balik.

Demikian juga dengan Sarafino (1998) hampir sama dengan pendapat sebelumnya bahwa terdapat 5 tipe dukungan sosial yaitu: (1) dukungan emosional, melibatkan ekspresi empati dan perhatian yang berguna untuk mendapatkan kenyamanan, dorongan dan perasaan dicintai ketika tertekan; (2) dukungan penghargaan, meliputi ekspresi pengahargaan positif, menyetujui ide-ide dan perasaan seseorang, bermanfaat bagi keyakinan diri, kemampuan dan perasaan berharga. Dukungan ini digunakan ketika seseorang melakukan penilaian terhadap tuntutan sumber-sumber personalnya yang menimbulkan stress; (3) dukungan instrumental, berupa bantuan langsung berbentuk materi seperti uang dan peralatan yang berguna untuk membantu mengurangi beban masalahnya; (4) dukungan informasi, dukungan ini melibatkan pemberian, saran, nasihat, sugesti maupun umpan balik mengenai apa yang harus dilakukan; (5) dukungan jejaring atau sosialisasi, meliputi penyediaan keanggotaan dalam suatu kelompok atau komunitas tempat individu melakukan aktivitas sosial.

Selanjutnya House dan Kahn (Cohen dan Syme, 1985) mengemukakan ada 4 jenis dukungan sosial yaitu: (1) dukungan emosional dimana aspek ini berhubungan dengan kondisi seseorang yang senantiasa memerlukan penghargaan, perhatian dan kepercayaan. Dukungan yang dibutuhkan individu berupa empati, cinta dan kepercayaan dari orang lain; (2) dukungan informasi, yaitu dukungan yang bewujud informasi di mana tujuannya untuk mengatasi masalah dan menyelesaikan jalan keluarnya. Dukungan ini dapat berupa nasehat, saran, pengarahan, bimbingan atau hanya sekedar pemberitahuan; (3) dukungan instrumental, di mana dukungan ini berhubungan dengan bantuan sarana dan prasarana berupa tempat tinggal, kebutuhan pangan, uang, sarana transportasi dan segala hal yang menyangkut fasilitas kehidupan sehari-hari; dan (4) dukungan penilaian, di mana dukungan ini berkaitan dengan penilaian yang bersifat positif yang akan membantu individu meningkatkan identitas diri serta pengembangan kepribadiannya. Dukungan ini berupa kritik, penilaian dan umpan balik dari keluhankeluhan permasalahan yang dihadapi.

Motivasimerupakankonsepyangmenguraikan kekuatan yang ada di dalam diri seseorang yang mengawali dan mengarahkan perilaku untuk bekerja (Gibson, 1996). Motivasi mengarahkan seseorang untuk menjalankan suatu pekerjaan sesuai dengan potensi yang dipunyai. Motivasi bisa meningkatkan semangat individu dalam menjalankan aktivitasnya, termasuk kemandirian dalam menjalankan usaha industri pangan bidang industri pangan. Motivasi didefinisikan sebagai dorongan dari dalam diri individu di mana berperilaku dengan cara tertentu untuk memenuhi keinginan atau kebutuhannya (Gibson, 1996). Kebutuhan adalah segala sesuatu yang apabila tidak terpenuhi maka akan berakibat munculnya ketidak seimbangan fisiologis maupun psikologis.

Hasil studi Umstot (1988) menjelaskan bahwa motivasi merupakan proses yang menyebabkan perilaku diberi energi, diarahkan, dan berlanjut. Perilaku biasanya diberi energi atau semangat oleh keinginan atau kebutuhan yang belum terpenuhi. Kebutuhan (needs) adalah suatu disposisi potensial dalam diri individu yang harus ditanggapi atau dipenuhi relevan dengan karakter, intensitas dan jenisnya. Motivasi yaitu usaha untuk memunculkan 
stimulus, dorongan atau pengungkit tenaga pada seseorang atau sekelompok masyarakat sehingga mau berbuat dan bekerja bersama secara maksimal melakukan sesuatu yang telah diagendakan untuk mengapai tujuan yang telah ditetapkan.

Berkaitan dengan motivasi Maslow mengkategorikan kebutuhan manusia menjadi lima yang tersusun dalam suatu hirarki kepentingan, yaitu fisiologis (psysiological), keamanan dan keselamatan (safety and security), rasa memiliki, sosial dan kasih sayang (belongingness, social, and love), dihargai (esteem), dan aktualisasi diri (self actualization). Menurut Maslow, kebutuhan dasar (fisiologis) harus dipenuhi terlebih dulu sebelum kebutuhan tingkat yang lebih tinggi seperti aktualisasi diri mengarahkan perilaku seseorang. Suatu keperluan yang telah terpenuhi berhenti menjadi motivator utama dari perilaku dan digantikan kebutuhan selanjutnya yang dominan. Manusia akan bertindak untuk mencukupi keperluan yang paling penting sesuai waktu, keadaan, dan pengalaman yang bersangkutan mengikuti suatu hirarki (Gibson, 1996).

Alderfer's membedakan kebutuhan manusia menjadi tiga kebutuhan, yang dijelaskan dalam Gambar 1.

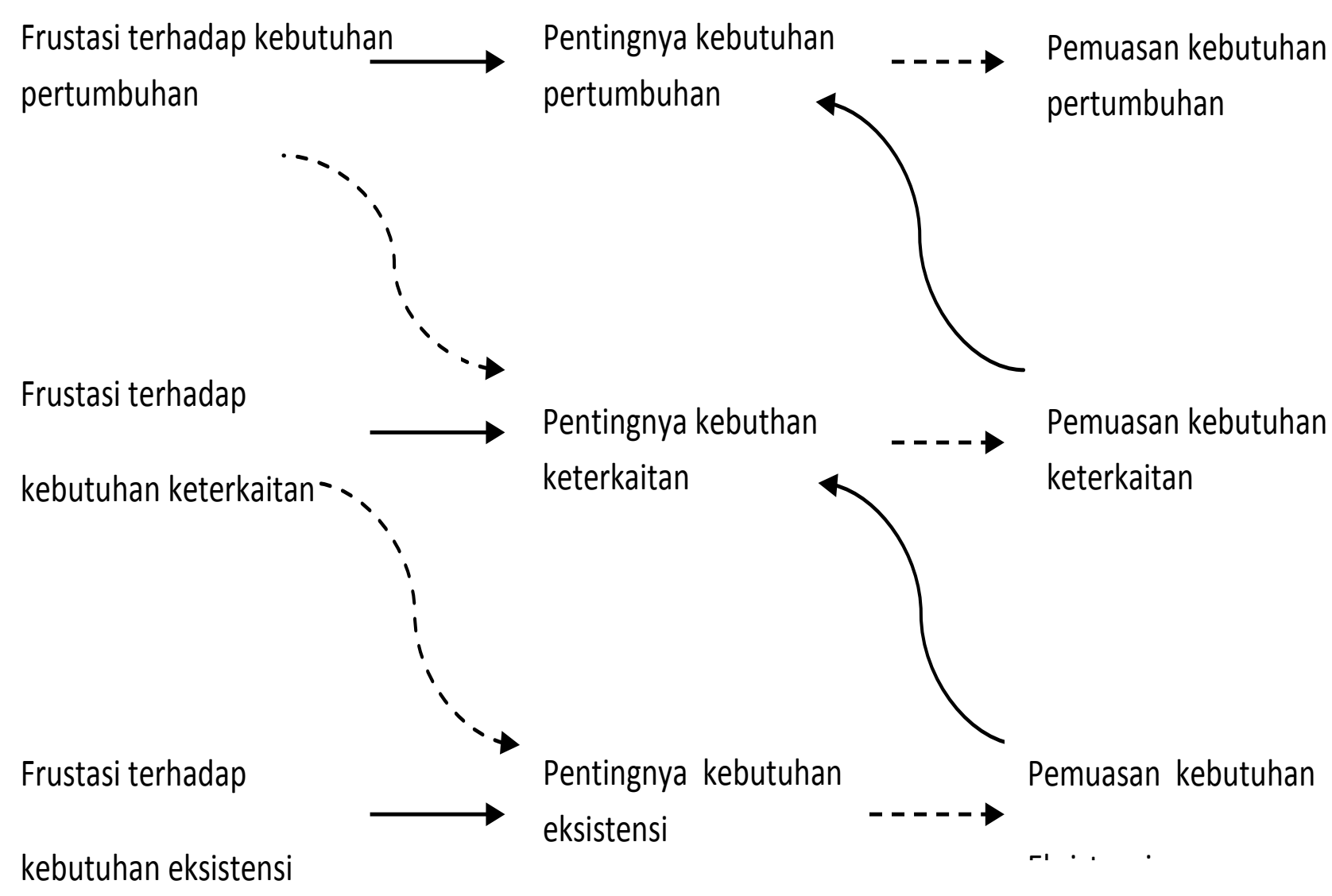

Gambar 1. ERG Theory Relationships among Frustration, Importance, and Satisfaction of Needs 
mencapai kepuasan dari perilaku eksploratif, mampu memanipulasi lingkungannya. Kemandirian dalam studi ini diukur dari kemampuan memanfaatkan sumber daya, kemampuan mengatasi hambatan, kemampuan menyesuaikan diri, dan kemampuan mengambil keputusan (Johnson dan Medinus, 1974; Crow and Crow, 1975; Ife dan Tesoriero, 1995; Verhagen, 1987; Spancer dan Kass, 1970; Banardib, 2002; Farid, 2008).

Social support mengacu pada Cohen dan Syme (1985), Sarafino (1998), McArthur (2007) bahwa social support dapat berupa dukungan emosi, dukungan informasi, dukungan instrumental, dukungan penghargaan, dukungan jejaring atau sosialisasi. Social support dalam studi ini diukur dari adanya dukungan dari keluarga, teman, pemimpin, petugas pemberdayaan perempuan, dan pelaku lembaga lain. Motivasi kerja, mengacu pada teori yang dikemukakan oleh Alderfer's bahwa motivasi kerja seseorang diukur melalui tiga dimensi yaitu: kebutuhan existence, kebutuhan relatednes; dan kebutuhan growth (Gibson et al., 1997; Terry, 1986; Gibson, 1996). Berdasarkan penjelasan di atas, dirumuskan hipotesis penelitian yang menduga bahwa variabel social support dan variabel motivasi secara simultan mempengaruhi kemandirian wanita tani dalam usaha di bidang industri pangan.

\section{Metode Penelitian}

Penelitian ini, menggunakan pendekatan kuantitatif yang didukung informasi kualitatif. Penelitian dilakukan dengan teknik survei yang berlokasi di Solo Raya Jawa Tengah, Indonesia. Populasi dalam studi ini adalah semua wanita tani yang melakukan usaha industri pangan. Berdasarkan kontruksi teori, kondisi empiris digambarkan atas tiga variabel, yaitu: variabel kemandirian sebagai variabel endogen, variabel dukungan sosial dan motivasi sebagai variabel endogen dan eksogen dari variabel yang lain, sedangkan social support sebagai variabel eksogen.

Pengambilan sampel penelitian menggunakan teknik multi stage random sampling sebanyak 210 responden. Pengambilan data primer dengan wawancara menggunakan kuesioner dan observasi langsung di lapangan terhadap subyek wanita tani yang melakukan usaha industri pangan. Data ketiga variabel tersebut berbentuk skor ordinal, kemudian diolah terlebih dahulu menjadi skala interval, dengan menggunakan skala model Likert agar dapat diolah dengan statistik parametrik (Suryabrata, 2000).

Data kemudian dianalisis validitas dan reliabilitasnya dengan menggunakan Cronbach Alpha, dengan kriteria apabila koefisien Cronbach Alpha lebih besar dari 0,60 maka dikatakan reliabel (Ghozali, 2011). Untuk mengonfirmasi apakah variabel observed secara bersama-sama dapat menjelaskan variabel laten digunakan analisis faktor. Analisis pengaruh variabel eksogen terhadap variabel endogen digunakan analisis structural equation modeling (SEM) dengan AMOS 18. Beberapa parameter untuk menilai fit tidaknya suatu model persamaan struktural menggunakan: (1) Chi-Square (c2) dan probabilitas; (2) Nilai RMSEA (The Root Mean Square Error of Approximation); (3) Nilai GFI (Goodness of fit Index); (4) Nilai AGFI (Adjusted Goodness of Fit Index); (5) Nilai NFI (Normed Fit Index); (6) Nilai CFI (Comparative Fit Index); (7) CMIN/ DF (The Minimum Sample Discrepancy Function Devided with degrre of Free-dom), seperti disampaikan oleh (Ghozali, 2011; Hair et al., 1998).

\section{Hasil dan Pembahasan}

\section{Analisis Deskriptif}

Wanita tani dalam menjalankan usaha industri pangan di Solo Raya mempunyai social support yang sedang, motivasi tinggi, dan kemandirian tinggi, hasil penghitungan disajikan pada Tabel 1.

Konstruk social support terdiri atas lima manifes yaitu: dukungan keluarga, dukungan teman, dukungan pemimpin, dukungan petugas, dan dukungan dari pelaku lembaga lain. Dari hasil analisis kategori, dukungan keluarga termasuk dalam kategori sedang, artinya keluarga wanita tani baik itu suami, anak, atau kerabat yang lain kadang-kadang memberi dukungan berupa memberi informasi, dukungan emosi, dukungan instrumental, dukungan penghargaan mengenai permodalan, proses produksi, pemasaran, pembukuan dan kemitraan.

Dukungan teman termasuk dalam kategori rendah, artinya teman wanita tani, baik teman sesama usaha maupun teman dalam kelompok, jarang memberikan dukungan informasi, dukungan emosi (memberikan semangat), memberikan dukungan fasilitas, maupun dukungan yang berupa penghargaan yang berkaitan dengan permodalan, proses produksi, pemasaran, pembukuan, dan kemitraan. Artinya tidak 
Tabel 1. Distribusi Kategori Wanita Tani dalam Usaha Industri Pangan di Solo Raya Jawa Tengah

\begin{tabular}{|c|c|c|c|c|c|c|}
\hline \multirow{3}{*}{ Variabel/ Indikator } & \multicolumn{6}{|c|}{ Kategori } \\
\hline & \multicolumn{2}{|c|}{ Rendah } & \multicolumn{2}{|c|}{ Sedang } & \multicolumn{2}{|c|}{ Tinggi } \\
\hline & $\mathbf{n}$ & $\%$ & $\mathbf{n}$ & $\%$ & $\mathbf{n}$ & $\%$ \\
\hline Dukungan keluarga & 44 & 21,0 & 109 & 51,9 & 57 & 27,1 \\
\hline Dukungan teman & 120 & 57,6 & 64 & 30,5 & 25 & 11,9 \\
\hline Dukungan pemimpin & 180 & 85,7 & 24 & 11,4 & 6 & 2,9 \\
\hline Dukungan petugas & 197 & 93,8 & 11 & 5,2 & 2 & 1,0 \\
\hline Dukungan pelaku lembaga lain & 175 & 83,3 & 26 & 12,4 & 9 & 4,3 \\
\hline Dukungan sosial & 70 & 33,3 & 110 & 52,4 & 30 & 14,3 \\
\hline Motivasi exsistence & 0 & 0,0 & 7 & 3,3 & 203 & 96,7 \\
\hline Motivasi relatedness & 0 & 0,0 & 2 & 1,0 & 208 & 99,0 \\
\hline Motivasi growth & 1 & 5,0 & 11 & 5,2 & 198 & 94,3 \\
\hline Motivasi & 0 & 0,0 & 0 & 0,0 & 210 & 100,0 \\
\hline Kemampuan memanfaatkan sumberdaya & 14 & 6,7 & 114 & 54,3 & 82 & 39,0 \\
\hline Kemampuan mengatasi hambatan & 16 & 7,6 & 100 & 47,6 & 94 & 44,8 \\
\hline Kemampuan menyesuaikan diri & 5 & 2,4 & 108 & 51,4 & 97 & 46,2 \\
\hline Kemampuan mengambil keputusan & 0 & 0,0 & 0 & 0,0 & 210 & 100 \\
\hline Kemandirian & 3 & 1,4 & 82 & 39,0 & 125 & 59,5 \\
\hline
\end{tabular}

Sumber : Analisis Data Primer, 2014

banyak dukungan dari teman, baik itu teman dari dalam kelompok maupun teman di luar kelompok terhadap wanita tani dalam menjalankan usaha industri pangan baik dalam hal permodalan, proses produksi, pemasaran, pembukuan, maupun kemitraan.

Demikian juga dengan kategori jawaban subyek berkaitan dengan dukungan pemimpin. Untuk semua dimensi (meliputi permodalan, proses produksi, pemasaran, pembukuan, dan kemitraan) termasuk dalam kategori rendah. Wanita tani dalam menjalankan usaha industri pangan di bidang pangan jarang memperoleh dukungan dari pemimpin, baik pemimpin formal maupun in formal, baik dalam bentuk dukungan informasi, memberi semangat, maupun pemberian fasilitas.

Dukungan dari petugas pemberdayaan perempuan terhadap wanita tani dalam menjalankan usaha industri pangan juga termasuk dalam kategori rendah, baik dukungan terhadap permodalan, proses produksi, pemasaran, pembukuan, maupun kemitraan, baik berupa dukungan berupa informasi, memberi semangat, maupun pemberian fasilitas. Demikian juga dengan dukungan pelaku dari lembaga lain yang terdiri dari dinas terkait, dari perguruan tinggi, maupun dari lembaga swadaya masyarakat terhadap wanita tani dalam menjalankan usaha industri pangan di bidang pangan juga termasuk dalam kategori rendah, baik dukungan dalam bentuk permodalan, proses produksi, pemasaran, pembukuan, maupun kemitraan.

Konstruk motivasi terdiri atas tiga variabel manifes yaitu: motivasi berusaha untuk memenuhi kebutuhan exsistence, relatedness, dan growth. Dari hasil analisis memperlihatkan bahwa motivasi exsistence wanita tani untuk melakukan usaha industri pangan di bidang pangan berada pada kategori tinggi. Motivasi untuk ingin dapat memenuhi kebutuhankebutuhan yang berkaitan dengan usaha yang sedang dijalankan tinggi. Motivasi tersebut meliputi motivasi ingin memperoleh tambahan modal usaha, ingin memperbaiki proses produksi dan pemasaran, ingin membuat pembukuan, dan ingin bermitra dengan pihak lain. Motivasi relatedness juga berada pada kategori tinggi, artinya di dalam menjalankan usaha industri pangan yang ditekuninya wanita tani juga ingin dianggap keberadaannya oleh orang lain yang ada di sekitarnya. Hasil studi ini relevan dengan hasil penelitian Suprayitna et al., (2012) bahwa motivasi memiliki pengaruh positif terhadap partisipasi. Motivasi growth wanita tani dalam menjalankan usaha industri pangan yang dijalankannya termasuk dalam kategori tinggi. Wanita tani juga ingin membuat atau mengembangkan produk inovasi baru dalam usaha yang sedang dijalankannya. Hal ini berarti mereka juga ingin dihargai atas semua apa ia lakukan.

Konstruk kemandirian terdiri atas empat 
variabel manifes yaitu: kemampuan memanfaatkan sumberdaya dalam usaha, kemampuan mengatasi hambatan dalam berusaha, kemampuan menyesuaikan diri dengan lingkungan usaha, kemampuan mengambil keputusan secara rasional. Hasil penghitungan skor menunjukkan bahwa kemampuan wanita tani dalam memanfaatkan sumberdaya untuk usahanya termasuk dalam kategori sedang, artinya wanita tani belum sepenuhnya dapat memanfaatkan sumberdaya yang dimilikinya, misalnya ketika suaminya panen singkong hanya kadang-kadang saja mereka mau menggolah dan menjual dalam bentuk makanan seperti tape atau singkong goreng. Dilihat dari kemampuan memanfaatkan permodalan termasuk dalam kategori tinggi, karena sebagian besar wanita tani sudah dapat mengakses modal pada sumber-sumber permodalan seperti BPR, PKK, dan PNPM. Proses produksi dalam kategori sedang, kondisi ini disebabkan karena mayoritas wanita tani masih menggunakan peralatan tradisional.

Pemasaran juga termasuk dalam kategori sedang, produknya hanya dipasarkan di sekitarnya. Sedangkan untuk dimensi pembukuan dan kemitraan termasuk rendah, kondisi di lapangan menunjukkan bahwa hampir semua wanita tani yang berusaha industri pangan tidak pernah membuat pembukuan atau catatan apapun dan juga tidak menjalin kemitraan. Kemampuan wanita tani dalam mengatasi segala hambatan dalam usaha termasuk dalam kategori sedang. Secara rinci terkait dengan kemampuan mengatasi hambatan dalam permodalan dan kemitraan termasuk kategori tinggi, proses produksi dan pemasaran termasuk dalam kategori sedang, adapun untuk dimensi pembukuan termasuk kategori rendah. Kemampuan wanita tani dalam menyesuaikan diri dengan lingkungan usaha termasuk dalam kategori sedang, demikian juga jika dilihat dari dimensi permodalan dan proses produksi termasuk kategori sedang, pemasaran termasuk kategori tinggi. Dari hasil wawancara mereka masih kesulitan untuk membuat pembukuan dan menjalin kemitraan dengan pihak lain. Kemampuan wanita tani dalam mengambil keputusan secara rasional dalam berusaha termasuk dalam kategori tinggi. Hasil penjelasan dari lapangan, mereka selalu mengambil keputusan sendiri dari apa yang akan dilakukan dalam usahanya, baik masalah permodalan, pemasaran, pembukuan, dan maunpun dalam menjalin kemitraan.

Berdasarkan hasil wawancara dan pengamatan di lapangan, wanita tani dalam menjalankan usaha jenis pangan, permodalan menjadi salah satu permasalahan yang utama bagi mereka yang ingin mengembangkan usahanya. Penyediaan modal dari sumber dana dapat diberikan sesuai kesepakatan bersama, melalui bunga lunak, dimensi proses produksi mereka tidak mengalami banyak kendala, namun penggunaan tehnologi dalam produksi mereka umumnya belum menggunakan. Mereka umumnya masih menggunakan teknologi sederhana sehingga mengakibatkan kualitas produk masih di bawah standar, dan kuantitasnya masih rendah. Dari dimensi pemasaran produk, mereka belum pernah melakukan promosi sebagai sarana untuk meningkatkan penjualan. Jangkauan pemasaran produk juga masih relatif terbatas dan memerlukan bantuan perluasan pemasaran, baik melalui pameran, memasok produknya ke toko-toko, atau ke tempattempat strategis lainnya, atau melalui penyediaan counter khusus bagi produk mereka.

\section{Analisis Kuantitatif}

Sebelum dilakukan analisis struktural untuk pengujian hipotesis terlebih dahulu dilakukan analisis confirmatory factor analysis (CFA), untuk menguji apakah variabel manifes yang telah dikembangkan sebagai pengukur konstruk laten dapat menjelaskan variabel laten yang ada. Analisis ini juga digunakan untuk menguji validitas suatu konstruk teoritis. Ukuran yang digunakan untuk menilai valid atau tidaknya manifest terhadap konstruknya adalah dengan melihat nilai loading factor pada output hasil analisis. Item manifest dikatakan valid apabila nilai standardized loading estimatenya tidak kurang dari 0,30 (Hair et al., 1998). Berdasarkan hasil analisis model pengukuran dengan CFA, diperoleh hasil bahwa terdapat dua manifes dari konstruk variabel social support yang memiliki loading factor di bawah 0,30 yaitu dukungan keluarga dengan nilai loading factor 0,22 dan dukungan petugas pemberdayaan perempuan sebesar 0,27 , sehingga manifes tersebut dikeluarkan dari analisis. Indikator dukungan teman memiliki nilai loading factor sebesar 0,92 , dukungan pemimpin 0,49 , dan dukungan pelaku lembaga lain sebesar 0,37 .

Konstruk motivasi memiliki tiga manifes yang ketiganya valid yaitu indikator existence memiliki nilai loading factor 0,65 , relatedness 0,78 , dan growth sebesar 0,61. Konstruk kemandirian memiliki empat manifes, dari hasil analisis semua indikator valid. Indikator/variabel manifes kemampuan memanfaatkan sumberdaya memiliki nilai loading 


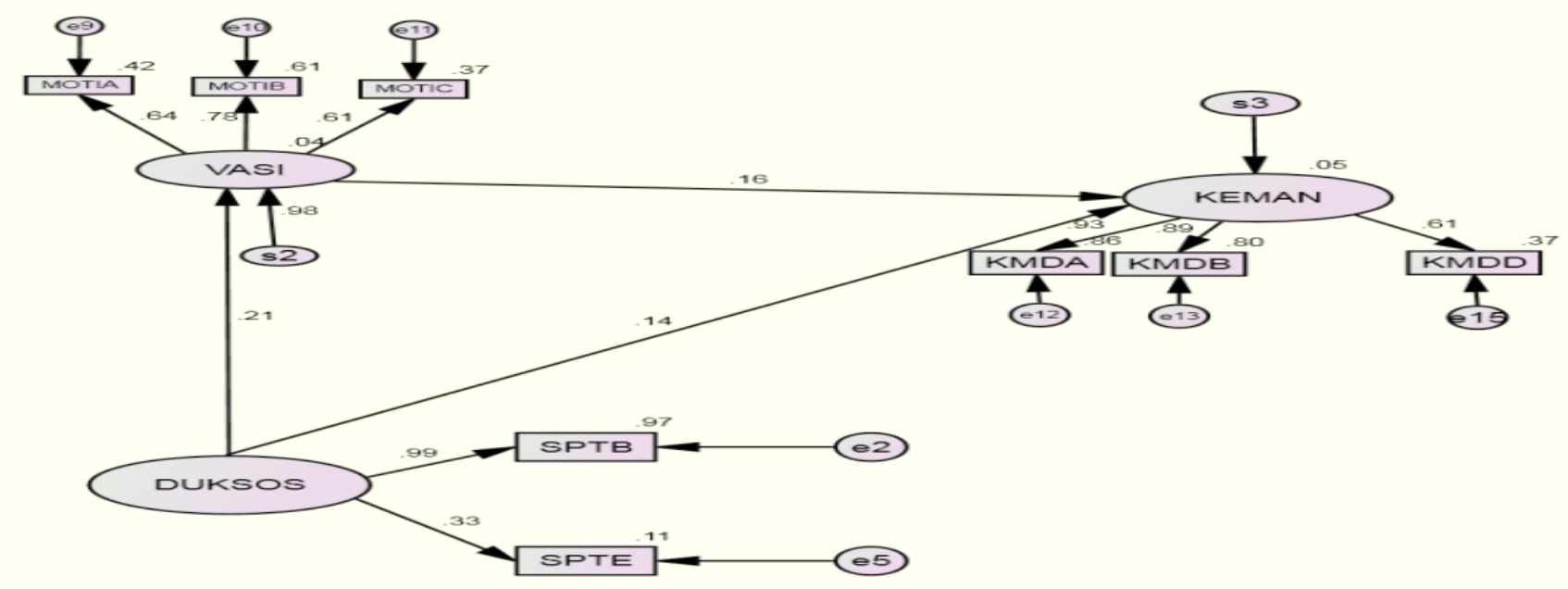

Keterangan:

$\begin{array}{llll}\text { DUKSOS } & \text { : Dukungan social } & \text { MOTIB } & \text { : Motivasi relatedness } \\ \text { SPTB } & \text { : Dukungan teman } & \text { MOTIC } & \text { : Motivasi growth } \\ \text { SPTE } & \text { : Dukungan pelaku lembaga lain } & \text { KEMAN } & \text { : Kemandirian } \\ \text { VASI } & \text { : Motivasi } & \text { KMDA } & : \text { Kemampuan memanfaatkan sumberdaya } \\ \text { MOTIA } & \text { : Motivasi existense } & \\ \text { KMDD } & \text { : Kemampuan mengambil keputusan secara rasional } & \\ \text { KMDB } & \text { : Kemampuan mengatasi hambatan dalam berusaha } & \end{array}$

Gambar 2. Model Modifikasi

Tabel 2. Hasil Uji Modifikasi Model Struktural/Indeks Kesesuaian Model

\begin{tabular}{lccc}
\hline \multicolumn{1}{c}{ Kriteria Goodness of Fit Index } & $\begin{array}{c}\text { Cut-off value } \\
\text { (nilai kritis) }\end{array}$ & Hasil Empiris & Evaluasi Model \\
\hline Chi-squares & $<39,17$ & 13,798 & Fit \\
Probability & $>0,05$ & 0,681 & Fit \\
CMIN/DF & $<2,00$ & 0,812 & Fit \\
GFI & $>0,90$ & 0,983 & Fit \\
AGFI & $>0,90$ & 0,965 & Fit \\
CFI & $>0,95$ & 0,989 & Fit \\
NFI & $>0,90$ & 0,959 & Fit \\
TLI & $>0,90$ & 1,000 & Fit \\
RMSEA & $<0,08$ & 0,000 & Fit \\
\hline
\end{tabular}

factor 0,91, kemampuan mengatasi hambatan sebesar 0,90, kemampuan menyesuaikan diri sebesar 0,86 , dan kemampuan mengambil keputusan dalam usaha 0,63 .

Ketiga konstruk pengukuran kemandirian, social support, dan motivasi dianalisis keterkaitannya dalam model struktural untuk menguji hipotesis, dengan melakukan uji kesesuaian model struktur dan uji efek terstandarisasi antar variabel laten. Uji kesesuaian (goodness of fit) model struktural melibatkan seluruh variabel laten beserta seluruh manifesnya secara bersama-sama. Hasil analisis 
seluruh variabel laten beserta manifesnya, dibandingkan dengan nilai acuan (cut off value). Nilai acuan yang harus dipenuhi agar model dapat dikatakan fit adalah nilai chi-squares sekecil mungkin dengan $p$-value $\geq 0,05$ (level of significancy), selain itu ada acuan lain seperti CMIN maksimal 2, GFI lebih dari 0,90, AGFI lebih dari 0,90, CFI lebih dari 0,95, NFI lebih dari 0,90, TLI lebih dari 0,90, dan RMSEA kurang dari 0,08 (Arbuckle JL. 1999; Santoso 2005).

Berdasarkan hasil analisis model hipotesis menunjukkan bahwa model tidak fit (chi-square $=$ 85,766 dengan $p=0,002$ ) meskipun nilai acuan lainnya sudah di atas 0,90. Karena model tidak fit, maka perlu dilakukan modifikasi model sehingga model bisa fit. Dengan menggunakan fasilitas indeks modifikasi (MI) ditunjukkan bahwa salah satu alternatif untuk memodifikasi adalah menghilangkan variabel yang errornya tinggi yaitu manifest dukungan pemimpin.

Pada Gambar 2 dan Tabel 2 dapat dilihat bahwa model modifikasi menunjukkan model sudah fit (chi-square $=13,798$ dengan probabilitas $=0,681$ $\geq 0,05$. Demikian juga dengan kriteria yang lain seperti GFI, AGFI, TLI diperoleh nilai diatas 0,90, RMSEA $=0,00$ kurang dari 0,08. Untuk itu pengujian hipotesis dapat dilakukan, dengan melihat nilai efek terstandarisasi antar variabel laten untuk menganalisis kekuatan pengaruh atau antar variabel laten di dalam model. Efek ini terdiri dari efek terstandarisasi langsung dan efek tidak langsung.

Pengaruh antar variabel laten beserta variabel manifes dalam model dapat dilihat pada hasil analisis regreesion weight dan standardized regression weightnya yang disajikan pada Tabel 3.

Hasil analisis pada Tabel 3 memperlihatkan bahwa ada pengaruh antar variabel laten, dimana $(\mathrm{p}<0,05)$ yaitu pengaruh social Support terhadap motivasi $(p=0,024)$ pengaruh motivasi terhadap kemandirian $(\mathrm{p}=0,018)$, dan social support terhadap kemandirian $(p=0,038)$.
Dalam Gambar 3 juga tampak bahwa kemandirian wanita tani dalam menjalankan usaha industri pangan bidang pangan memiliki koefisien determinasi kecil sekali yaitu 0,05 yang diperankan oleh social support, yang berarti kecil sekali pengaruh dukungan teman dan dukungan pelaku lembaga lain secara bersama dalam meningkatkan kemandirian wanita tani dalam menjalankan usaha industri pangan. Ini berarti bahwa masih ada 95 persen error serta fakor-faktor lain yang berpengaruh dan belum diteliti.

Motivasi dengan koefisien determinasi sebesar 0,04 yang diperankan social support terhadap motivasi. Hal ini berarti masih ada banyak faktor yang mempengaruhi motivasi yang belum terungkap dalam penelitian ini. Dapat juga dikatakan bahwa dukungan teman dan dukungan pelaku lembaga lain juga hanya sedikit pengaruhnya dalam meningkatkan motivasi perempuan rumah tangga miskin dalam memenuhi kebutuhannya. Efek langsung, efek tidak langsung, dan efek hasil total dari variabel social support dan motivasi terhadap kemandirian wanita tani dalam menjalankan usaha industri pangan di bidang pangan dapat dlihat pada Tabel 4.

Hasil efek terstandarisasi antar variabel pada Tabel 4 menunjukkan bahwa social support secara langsung meningkatkan kemandirian. Motivasi juga secara positif dan signifikan meningkatkan kemandirian. Efek secara tidak langsung yaitu social support dimediasi oleh motivasi meningkatkan kemandirian, dengan efek total lebih besar 0,033 daripada efek secara langsung. Motivasi mempunyai efek langsung positif signifikan terhadap kemandirian, tetapi efek total tidak menunjukkan penguatan 0,000 .

\section{Hasil Pengujian Model}

Hasil analisis model struktural menunjukkan bahwa model hipotetis setelah dimodifikasi memenuhi

Tabel 3. Regreesion Weight dan Standardized Regression Weight Modifikasi Model Struktural

\begin{tabular}{|c|c|c|c|c|c|c|}
\hline Pengaruh & Antar Variabel & Estimate & $\mathbf{S E}$ & $\begin{array}{c}\text { Estimasi } \\
\text { Terstandard }\end{array}$ & $\begin{array}{c}\text { Critical Ratio } \\
\text { (CR) }\end{array}$ & Prob. \\
\hline Motivasi & $<--$ Social Support & 0,950 & 0,419 & 0,192 & 8,276 & $0,024 * *$ \\
\hline Kemandirian & $<--$ Motivasi & 0,351 & 0,102 & 0,187 & 6,510 & $0,018 * *$ \\
\hline Kemandirian & $<--$ Social Support & 0,412 & 0,096 & 0,141 & 6,236 & $0,038 * *$ \\
\hline Keterangan: & $\begin{array}{l}=\text { signifikan } \mathrm{p} \\
=\text { signifikan } \mathrm{p}\end{array}$ & $\begin{array}{l}\alpha=1 \% \\
\alpha=5 \%\end{array}$ & & & & \\
\hline
\end{tabular}


Tabel 4. Efek Terstandaridisasi antar Variabel Laten

\begin{tabular}{lccc}
\hline \multicolumn{1}{c}{ Variabel Laten } & Efek Langsung & Efek Tidak Langsung & Efek Total \\
\hline Social Support & 0,413 & 0,033 & 0,176 \\
Motivasi & 0,157 & 0,000 & 0,157 \\
\hline
\end{tabular}

syarat kesesuaian model (chi-squares $=13,798, \mathrm{p}$ $=0,681)$. Berdasarkan hasil tersebut maka model teoritis keterkaitan antara social support, motivasi dan kemandirian wanita tani dalam menjalankan usaha industri pangan memenuhi syarat kesesuaian model.

Hal ini menunjukkan bahwa social support berpengaruh positif signifikan terhadap kemandirian, meskipun hanya dari dukungan teman, dan dukungan pelaku lembaga lain (dinas terkait lainnya seperti Badan Pemberdayaan Masyarakat/Bapermas dengan program PNPMnya dalam bentuk pemberian pinjaman modal untuk usaha dan adanya pelatihanpelatihan untuk peningkatan kemampuannya). Dukungan teman berupa pemberian informasi yang berkaitan dengan permodalan, pembelian bahan baku, dan pemasaran.

Selanjutnya social support juga berpengaruh positif signifikan terhadap motivasi existence yaitu motivasi untuk memenuhi kebutuhan mempertahankan keberadaan seseorang dalam hidupnya. Kebutuhan tersebut akan terpuaskan oleh faktor seperti makanan, udara, air, keuntungan dan kondisi pekerjaan untuk memenuhi kebutuhan untuk tetap eksis menjalankan usaha industri pangan. Hal ini merupakan penyederhanaan dari kebutuhan fisiologis dan rasa aman dalam teori Maslow. Keterkaitan (relatedness needs), kebutuhan untuk berinteraksi dengan orang lain, yang terpuaskan dengan adanya hubungan sosial dan interpersonal yang berarti kebutuhan ini identik dengan kebutuhan sosial dan harga diri dalam teori Maslow. Hal ini didukung oleh hasil studi dari Kumaran dan Anand (2016) yang menunjukkan bahwa ada pengaruh yang signifikan karakteristik sosial dan pribadi terhadap motivasi untuk melakukan usaha.

Pertumbuhan (growth needs), kebutuhan pengembangan diri yang terpuaskan dengan menciptakan kontribusi yang kreatif dan produktif. Penelitian ini mendukung hasil studi Toding dkk (2015) yang menunjukkan bahwa terdapat hubungan positif yang signifikan antara dukungan sosial dengan motivasi berprestasi. Dalam studi ini Teori ERG dari Alderfer's yang menyatakan bahwa individu termotivasi berperilaku untuk memuaskan satu dari 3 (tiga) kelompok kebutuhan atau ketiganya sekaligus dan tidak harus hirarkhi. Kondisi tersebut lebih relevan dengan kondisi wanita tani dalam menjalankan usaha, dibandingankan dengan teorinya Maslow, dimana pemenuhan kebutuhan harus dilakukan secara hirarkhi.

Motivasi wanita tani dalam menjalankan usaha industri pangan juga memiliki pengaruh positif yang signifikan terhadap kemandirian usaha industri pangan. Motivasi wanita tani dalam menjalankan usaha industri pangan cukup tinggi dan berkontribusi terhadap kemandirian. Penelitian ini mendukung hasil penelitian Firmansyah (2015) yang menyatakan bahwa motivasi dapat mempengaruhi kinerja. Hal ini dapat dijelaskan bahwa dengan adanya motivasi dapat memberikan energi secara langsung dan terus menerus untuk selalu memenuhi kebutuhan usahanya, seperti modal usaha, peralatan produksi, mitra usaha, dan pemasaran. Selain itu, motivasi wanita tani yang tinggi juga disebabkan karena adanya kebutuhan keluarga yang harus mereka penuhi seperti makan, minum, pakaian, bayar listrik, saku sekolah anakanak, dan yang tidak kalah pentingnya lagi adalah kebutuhan untuk sosial seperti "jagong".

Hasil efek terstandardisasi antar variabel laten dalam model memperlihatkan bahwa motivasi berpengaruh positif signifikan terhadap kemandirian. Hasil efek terstandarisasi antar variabel laten dalam model menunjukkan bahwa social support mempunyai pengaruh positif signifikan terhadap kemandirian. Hasil efek terstandarisasi antar variabel laten dalam model menunjukkan bahwa efek tidak langsung social support jika dimediasi oleh motivasi pengaruhnya lebih besar terhadap kemandirian dibandingkan dengan efek langsung.

Berdasarkan hasil penelitian yang telah dilakukan, agar supaya wanita tani dapat mandiri untuk melakukan usaha industri pangan, diperlukan dukungan dari teman dan dukungan dari pelaku lembaga lain seperti perguruan tinggi, lembaga swadaya masyarakat, dan badan pemberdayaan masyarakat dalam bentuk program PNPM-nya, sedangkan dukungan keluarga, tidak mendukung laten social support. Hasil model pengukuran social support tersebut, juga tidak mendukung hasil 
penelitian terdahulu yang membuktikan bahwa dukungan keluarga merupakan hal penting yang harus dilakukan dalam aktivitas yang dilakukan oleh anggota keluarga yang bersifat emosional dan instrumental (Kaufman \& Behrr dalam Adams, et al., 1996). Demikian juga dengan hasil studi yang dilakukan oleh Johnson dan Johnson (2000) yang menyatakan bahwa: social support bersumber dari orang-orang dekat dengan individu yang membutuhkan bantuan seperti keluarga, teman, komunitas sosial seperti organisasi, tempat kerja, dan sekolah.

Hal ini dapat dijelaskan bahwa dukungan sosial dari keluarga yang bersumber dari anggota keluarga, seperti: anak, suami, orang tua, adik, kakak, dan kerabat pada studi sebelumnya seringkali dikaitkan dengan masalah kesehatan tetapi jarang yang mengkaitkannya dengan outcome yang berkaitan dengan pekerjaan.

Dukungan keluarga dalam studi ini, tidak mencerminkan laten social support, karena dalam menjalankan usaha industri pangan wanita tani merasa bahwa pekerjaan dan keluarga merupakan dua ranah yang saling mendukung, yang ketika seseorang ingin memperoleh kesejahteraan dalam keluarga, mereka harus bekerjasama. Untuk itu, maka sudah seharusnya dan sewajarnyalah apabila keluarga juga turut mendukung atau membantu apa yang dilakukan oleh anggota keluarga yang lainnya. Hal ini ditunjukkan oleh adanya dukungan keluarga kepada wanita tani dalam menjalankan usaha industri pangan memperoleh tingkat capaian sebesar 51,9 persen. Artinya, keluarga (suami, anak, dan kerabat yang lain) kadang-kadang membantu wanita tani dalam menjalankan usahanya, karena anggota keluarga yang lain juga memiliki kesibukan lain yang juga ditujukan untuk memenuhi kebutuhan keluarga. Selain itu, hubungan di antara anggota keluarga sudah merupakan suatu ikatan yang kuat yang harus saling menjaga, dan bukan dianggap sebagai dukungan lagi tetapi sebagai sesuatu yang memang harus mereka lakukan.

Dalam konteks rumah tangga, seperti halnya rumah tangga pertanian, Nakajima (1986)menjelaskan bahwa rumah tangga mempunyai sumberdaya agar dapat memberikan kepuasan dan dapat dibagi di antara anggota keluarga. Dalam hal ini rumah tangga dapat dikatakan sebagai satu unit produksi sehingga anggota rumah tangga merupakan satu kesatuan yang secara otomatis saling membantu satu dengan yang lain. Konsep rumah tangga menurut Nakajima (1986) bahkan dianggap sebagai suatu unit ekonomi yang kompleks, yaitu sebagai perusahaan, tenaga kerja keluarga dan konsumen yang memaksimumkan utilitas.

Dukungan dari teman sesama usaha dalam hal ini dapat berupa dukungan dalam bentuk pemberian informasi tentang permodalan, pembelian bahan baku, perbaikan proses produksi, dan informasi mengenai pemasaran produk, sedangkan informasi yang berkaitan dengan pembukuan, kemitraan dan pemberian fasilitas seperti modal maupun peralatan untuk produksi, teman sesama usaha tidak banyak mendukung.

Dukungan dari lembaga lain, dalam hal ini adalah dukungan dari instansi manapun selain dukungan dari kantor pemberdayaan perempuan. Dalam studi ini, lembaga lain yang dapat memberi dukungan adalah lembaga Badan Pemberdayaan Masyarakat dalam bentuk program PNPM. Bentuk dukungannya bukan memberikan informasi tentang permodalan, proses produksi, pembukuan, pemasaran dan kemitraan, tetapi lebih banyak dalam bentuk pemberian pinjaman modal usaha dengan bunga lunak yaitu sebesar $2 \%$ per bulan.

Berhubungan dengan kemandirian wanita tani, dukungan teman dan dukungan pelaku lembaga lain akan lebih baik apabila dimediasi dengan motivasi exsistence needs bahwa wanita tani dalam pemenuhan kebutuhan pangan (ingin dapat makan nasi tiga kali sehari dengan lauk meskipun hanya dengan tempe, karak, krupuk atau ikan asin). Hal ini relevan dengan hasil studi Charatsari et al., (2017) yang menunjukkan bahwa partisipasi dalam dipengaruhi oleh motivasi baik intrinsik dan yang memiliki kebutuhan untuk mandiri.

Demikian juga dengan pemenuhan kebutuhan akan sandang, mereka juga ingin dapat memakai pakaian yang berbeda ketika mereka pergi ke pasar, pergi pengajian/arisan, pergi jagong dengan pakaian yang mereka gunakan ketika di rumah atau ketika berjualan. Selain motivasi relatedness needs untuk pemenuhan kebutuhan-kebutuhan tersebut, wanita tani juga menginginkan adanya pemenuhan kebutuhan ingin dihargai oleh lingkungannya. Hal ini dapat ditunjukkan bahwa mereka akan merasa sedih apabila ada tetangga atau teman yang punya "gawe" (mantu/"tetak'an"/sunatan") mereka tidak diundang baik untuk "rewang" maupun untuk menghadiri acara tersebut. Terlebih lagi mereka akan merasa malu jika diundang tetapi tidak bisa hadir, rasa malu ini katanya melebihi rasa malunya ketika mereka ketemu orang yang mereka hutangi 
tetapi belum bisa bayar. Selanjutnya dalam waktu yang bersamaan wanita tani juga memiliki motivasi growth, yang diperlihatkan bahwa mereka juga ingin dihargai oleh orang lain, misalnya mereka akan merasa banga atau senang sekali ketika ada orang lain yang mengatakan bahwa masakan yang dijual rasanya lezat sekali. Semua kondisi yang dilakukan oleh wanita tani dalam mejalankan usaha industri pangan tersebut mendukung Teori ERG dari Alderfer yang menyatakan bahwa individu termotivasi berperilaku untuk memuaskan satu atau lebih dari 3 (tiga) kelompok kebutuhan tersebut dan tidak harus tersusun secara hirarkhi.

Kemandirian wanita tani dalam menjalankan usaha industri pangan ditunjukkan oleh adanya: (1) kemampuan untuk memanfaatkan sumberdaya yang ada seperti memanfaatkan informasi yang diperoleh dari teman sesama usaha untuk mengakses modal usaha, kemampuan untuk mengajukan pinjaman modal ke PNPM; (2) kemampuan mengatasi hambatan dalam usaha, hal ini mereka tunjukkan misalnya agar dapat mengangsur pinjaman secara rutin dan tepat waktu maka mereka melakukannya dengan cara menabung setiap hari yang dimasukan dalam kaleng; (3) kemampuan mengambil keputusan secara rasional, dalam kaitannya dengan usaha yang mereka lakukan wanita tani dapat mengambil keputusan sendiri secara rasional, yang ditunjukkan dalam hal misalnya ketika dagangannya tidak laku semua mereka tidak lantas menjual selakunya dengan harga murah (di bawah standar) tetapi produk mereka dibawa pulang untuk diberikan secara cuma-cuma kepada sanak saudaranya atau tetangga, dengan alasan kalau dijual murah nanti pembeli tuman (ketagihan), artinya pembeli akan selalu minta harga di bawah standar.

\section{Kesimpulan}

Berdasarkan hasil studi dan pembahasan dapat disimpulkan bahwa motivasi dapat meningkatkan kemandirian wanita tani dalam menjalankan usaha industri pangan. Social support juga dapat meningkatkan kemandirian wanita tani untuk melakukan usaha industri pangan. Social support memiliki pengaruh yang lebih besar terhadap kemandirian wanita tani jika dimediasi oleh motivasi. Dalam meningkatkan kemandirian wanita tani dalam usaha industri pangan di Solo Raya perlu meningkatkan motivasi wanita tani terlebih dahulu sebelum meningkatkan kemandiriannya dalam menjalankan usaha industri pangan. Social support dari teman, dan dari pelaku lembaga lain seperti Bapermas (PNPM), perguruan tinggi, dan lembaga swadaya masyarakat, maupun dinas terkait lainnya (Dinas Pertanian, BKKBN, Deperindagkop) juga perlu ditingkatkan karena mempunyai kontribusi dalam meningkatkan kemandirian. Support dari berbagai pihak selain memberikan sarana prasarana yang sesuai dengan usaha industri pangan yang dijalankan oleh wanita tani, sebaiknya dalam bentuk pembelajaran dan bukan dalam bentuk charity agar kontribusinya untuk meningkatkan kemandirian lebih tinggi.

\section{Acknowledgements}

Artikel ini merupakan bagian dari hasil penelitian hibah unggulan perguruan tinggi Universitas Sebelas Maret. Para penulis mengucapkan terima kasih kepada Universitas Sebelas Maret yang telah membiayai penelitian ini melalui Dana DIPA BLU Universitas Sebelas Maret.

\section{Daftar Pustaka}

Adams GA, King LA, King DW. 1996. "Relationship of Job and Family Involvement, Family Social Support, and Work-family Conflict With Job and Life Satisfaction", Journal of Applied Psychology. 81(4): 411-420.

Arbuckle JL. 1999. Amos Users' Guide Version 6. SmallWaters Corporation.

Barnadib SI. 2002. Identifikasi Proses dan Peristiwa Pendidikan, Yogyakarta (ID): FIP IKIP Yogyakarta.

Betz NE. 2007. "Career Self Efficacy: Exemplary Recent Research and Emerging Direction", Journal of Career Assessment. (15): 403.

Brawer FB. 1973. Human Intelligence its Nature and Assesment, New York (US): Harper \& Row Publisher.

Charatsari C, Evagelos D, Lioutas, Alex K. 2017. Farmers Motivational Orientation Toward Participation in Competence Development Projects: a Self-deternimation theory Perspective. Journal of Agricultural Education and Extension. 23: 105-120.

Chaundhry SI. Nosheen F. 2009. The Determinant of Woman Empowerment in Southern Punjab (Pakistan): An Empirical Anylisis. (24): 217 
$-228$.

Cohen S, Syme SL. (Eds). 1985. Social Support and Health. Orlando (US): Academic Press, Inc.

Crow A, Crow LD. 1975. Educational of Psychology, New Jersey (US): Totawa Adam \& Co.

Crow LD, Crow A. 1993. General Psychology, New Jersey (US): Littlefield.

Farid A. 2008. Kemandirian Petani dalam Pengambilan Keputusan Usahatani Kasus Petani Sayuran di Kabupaten Bondowoso dan Kabupaten Pasuruhan. [Disertasi]. Bogor (ID): Institut Pertanian Bogor.

Ferdinand A. 2004. Structural Equation Modeling dalam Penelitian Manajemen. Semarang (ID): Diktat Fakultas Ekonomi UNDIP.

Firmansyah, Siti A, Dwi S. 2015. Motivasi, Kepuasan Kerja dan Kinerja Penyuluh Kehutanan di Kabupaten Cianjur Jawa Barat. Jurnal Penyuluhan. 11(1). Bogor (ID): Institut Pertanian Bogor.

Gibson JL, Ivancevich JM, Donnelly JH. 1996. Organizations: Behavior, Structure, Processes, Chicago (US): IRWIN.

Gibson JL, Ivancevich JM, Donnely JH. 1997. Organisasi dan Manajemen, Perilaku Stuktur Proses. Jakarta (ID): Erlangga.

Ghozali I. 2011. Aplikasi Analisis Multivariate Dengan Program IBM-SPSS 19. Semarang (ID): Universitas Diponegoro.

Hair JF, Black WC, Babin BJ, Anderson RE, Tatham RL. 1998. Multivariate Data Analysis, Sixth Edition, New Jersey (US): Prentice-Hall International.

House J, Smet. 1994. Measures and Concept of Social Support. Londoon (UK): Academic Press, Inc.

Ife J, Tesoriero F. 2008. Community Development: Alternatif Pengembangan Masyarakat di Era Globalisasi. Yogyakarta (ID): Pustaka Pelajar.

Johson DW, Johson EP. 2000. Joining Together: Group Theory and Group Skills. Boston (US): Prentice-Hall, Inc.

Johnson RC, Medinus GR. 1974. Child Psychology Behavior \& Development. New York (US): John Wiley \& Sons, Inc.

Kumaran M, Anand PR. 2016. Entrepreneurship Motivation of Fisheries Graduates: A Exploratory Study. Journal of Extension Education. 28(1): 5579-5587.
Mc Arthur CT. 2007. Sosial Support \& Social Conflict. [internet]. [dapat diunduh di: $<\underline{\mathrm{http}}: / /$ hsr.e-contentmanagement.com/].

Nakajima C. 1986. Subjective Equilibrium Theory of The Farm Household. Amsterdam Elsevier Science Publisher BV.

Santoso S. 2005, Buku Latihan SPSS Statistik Multivariat. Jakarta (ID): Penerbit PT. Alex Media Komputindo Gramedia.

Sarafino EP. 1998. Healt Psychology: Biopsychososial Intervention, Third Edition. New York (US): John Willey and Sons, Inc.

Schultz WC, Schultz. 1990. Psychology and Industry Today: An Introduction to Industrial And Organizational Psychology (5th ed). London (UK): Maxwell Macmillan International Editions.

Spancer TD, Kass N. 1970. Personality in Child Psychology, New York (US): Mc. Graw-Hill Book Company.

Sumodiningrat G. 1996. Pembangunan Daerah dan Pemberdayaan Masyarakat. Jakarta (ID): Gramedia.

Suprayitno AR, Sumardjo, Darwis SG, Basita GS. 2012. Motivasi dan Partisipasi Petani dalam Pengelolaan Hutan Kemiri di Kabupaten Maros Provinsi Sulawesi Selatan. Jurnal Penyuluhan. 9(2): 182-196.

Suryabrata S. 2000. Psikologi Kepribadian. Jakarta (ID): CV. Rajawali.

Umstot D. 1988. Understanding Organizational Behavior. New York: West Publishing Company.

Terry GR. 1986. Principles of Management. Eighth Edition. Terjemahan Winardi: Asas-Asas Manajemen. Cetakan IV. Bandung (ID): PT. Alumni.

Toding WRB, David L, Pali C. 2015. Hubungan Dukungan Sosial dengan Motivasi Berprestasi Pada Mahasiswa Angkatan 2013 Fakultas Kedokteran Universitas Sam Ratulangi. Jurnal e-Biomedik. 3(1): 146 - 151.

Verhagen KCW. 1996. Self Help Promotion, A Chalenge to The NGO Community,. Amsterdam: Royal Tropical Institute.

Watson RI, Lindgren. 1999. Psychology of The Child and The Adolesscent. New York (US): Mc. Milan Publishing Co. 